\title{
ICT AND QUALITY OF TEACHING-LEARNING RELATED ACTIVITIES IN PRIMARY SCHOOLS IN OGOJA EDUCATION ZONE OF CROSS RIVER STATE, NIGERIA
}

\section{BERNARD ATROGOR OKO AND MONITY FLORA MICHAEL}

(Received 10, November 2015; Revision Accepted 4, January 2016)

\begin{abstract}
The paper is a report of a study carried out to examine how information and communication technology (ICT) enhance teaching learning related activities in primary schools in Ogoja education zone of Cross River State, Nigeria. To achieve the purpose of the study, one research question was formulated to direct the study. Ex - post facto research design was adopted for the study. A sample of six hundred and twenty teachers were randomly selected for the study. The instruments for data collection were the ICT and teaching learning related activities questionnaire (ICTTLRAQ) developed by the researcher. The reliability estimate of the instrument was established through the cronbach alpha reliability method. To analyze the data, simple percentage was adopted. The result of the analysis revealed an enhancement of teaching learning related activities through the use of information and communication technology in Ogoja education zone. Based on the findings of the study, it was recommended that government should provide computer at affordable price to all teachers in the zone.
\end{abstract}

KEYWORDS: Information and technology, teaching and learning, Related activities and primary school

\section{INTRODUCTION}

The challenge for the teacher information and communications technologies present a range of tools that can be used by teachers to present and demonstrate as part of their teaching as well as something for pupils to use as part of an activity as individuals or in groups.

The drive towards greater use of technology in education is aimed at modernizing teaching and learning and equipping the pupils of today with skills that will make them able to use such technology in the workplace once they leave school. Other stated goals have been to reduce teacher work load by making planning and resources available over the internet or to reduce bureaucracy by providing and exchanging information in electronic form. These technological tools can be explicitly designed for use in education context such as a mathematics teaching program or an overhead projecting calculator or they can be equipment and software also used in other contexts, such as computer with data projectors, or word-processors and spreadsheets. The choice of when and how to use such technologies in teaching and learning activities is complex, the evidence above all clearly indicates that it is how ICT is used that makes the difference. The focus of this paper therefore, is on ICT and quality of teaching learning related activities in primary schools in Ogoja education zone of Cross River State, Nigeria.

\section{Literature Review}

There is a growing evidence that ICT application to the core business of education can accelerate and improve learning on a number of fronts, from basic skills (Maun, 1999; BECTA, 2000); Problem solving (Oliver \& Omari, 1999; Williams, 1999); information management (Peabody, 1996), work habits (Adnanes, 1998),

Bernard Atrogor Oko, Department of Curriculum and Teaching, University of Calabar, Calabar, Nigeria Monity Flora Michael, Department of Curriculum and Teaching, University of Calabar, Calabar, Nigeria 
motivation (Allen, 2000; Combs, 2000; Diggs, 1997; Sherry, 2001), establishing life-long learning habits (Schollie, 2001) and concepts development (Yelland, 1998).

According to Sutton (2006) ICT in education have been found to promote students' intellectual qualities through higher order thinking, problem solving, improved communication skills, and deep understanding of the learning tool and the concepts to be taught. ICT can promote a supportive, interactive teaching and learning environment, create learning communities, and provide learning tools for students, including those with special needs (Innidad, Aldndge \& Fraser, 2001; Harwkins, 2002).

Kosoko-oyedeko and Tella (2010), have noted that ICT is observed to help pupils to learn and enabling them to consolidate and deepen their knowledge, understanding and skills. According to NCA (2007) using ICT in teaching can help pupils to:

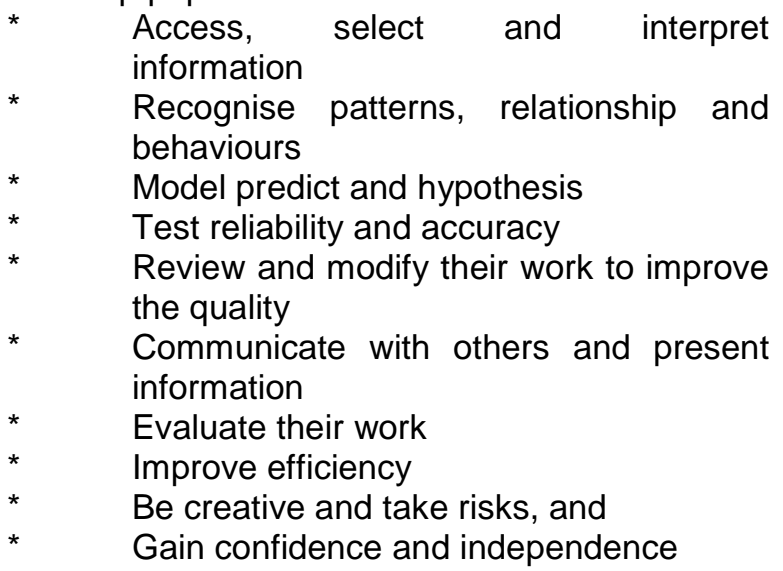

Kosoko-Oyedeko and Tella (2010) have noted that ICT is a powerful tool that can improve teaching and learning and can help to raise standards by encouraging pupils to ask questions to promote knowledge and understanding and shared human experience.

According to the duo, this can be achieved by using the internet on CD ROM sources, a database on spreadsheet and communication technologies (e-learning and video conferencing). Furthermore, ICT help to assess, evaluate and use a wide range of resources (e.g. internet and CDROMS) critically to develop understanding of subjects; understand, analyse and evaluate interpretations and argument; organise information and ideas to communicate meaning and understanding effectively (e.g. using a writing frame or concept mapping software; communicate (via e-mail or video conferencing) with organisations and experts etc.

There is evidence that ICT helps primary school teachers to be more effective in their teaching, especially if they are well resourced (Becta, 2000). Office for standard in education (2004) maintained that when pupils used ICT. Well, there was a clear improvement in the presentation of their work, in the range of information they had to draw on, in their capacity of enter imaginatively into other situations and in their understanding and analysis of key concepts.

It has been suggested that when digital content is integrated into curriculum, a change in the learning process, occurs (CEO forum, 1999), which is characterised as being.

$>$ Problems of project oriented - whereby investigations are authentic and there will be a variety of solutions to a problem.

$>$ Student- centred - so that students feel empowered in their work and participate in creating and developing their own investigations while their teachers guide, facilitate and provide them with materials to support their learning.

$>$ Collaborative - since learning with authentic task is an interactive experience between student and their teacher, as student acquire and use information, exchange ideas with each others and create relationship with professional relevant to their work.

$>$ Relevant - learning with ICT has the potential to create educational opportunities than needs of individuals and groups in diverse ways and allow them to work according to their needs and interests.

$>$ Productive - as the use of ICT encourage both student and teachers to be content producers, this has the added benefit that the level and quality of the productions is usually high in turn, this encourages student to engage with learning more effectively. The productions are not only in term of quality presentation and report but also in creating relationship extending beyond those in the immediate locality.

$>$ Lifelong- student develop skill in learning how to learn, which will benefit them in the long term and enable them to interact with people and ideas in a borderless manner (CEO forum, 1999: 10) Shefield, 
Enrich - fulcer and Brott (1994) however, found that there was an emerging literature that appear to indicate that one of the major benefits of using computer aided instruction (CAI) Was an increase in students general enthusiasm, which seemed to help average student in particular to learn more than if they had not used the technology.

Becker (1993) in considering the role of teachers articulated the characteristics of exemplary computer-using teachers. He found that they integrated computers into their program and created an environment for learning in which the computer use was not only directly related to their curriculum goals, but also incorporated a wide variety of uses for the machine across the curriculum. Becker(1993) noted that exemplary computer using teachers had greater access to formal professional development activities than other computer users he noted specifically that when directly related to specific subject areas, staff development in the use of generic software programs (eg. word processors) was beneficial.

\section{Theoretical background}

It is necessary that one has an insight into the background of theories that support a particular study and from where the problem may be identified and hypothesis formulated. The researcher examine ICT oriented micro models since the study dealt with ICT and quality of teaching-learning related activities.

Reiber and Welliver (1989) and later Marcinkicwicz (1994) developed the instructional transformation model which has been used by a number of researchers in the likes of Knee (1996) to help schools design their restructuring plan using technology. This model was developed from a study on adoption behaviour drawing on the CBAM model and the work of Rogers (1983). This saw much value to educators in the model, particularly in recommending staff, development, remediation, or differential staffing (Marcinkiewicz and Welliver, 1993). The instructional transformation model proposes a hierarchy for the successful application of technology to education using Levels of Use (LOU) type of approach. This hierarchy involves the following four steps:
(i) Familiarization
(ii) Utilisation
(iii) Integration
(iv) Re-orientation

These stages show that an educator has to progress through correspond Apple Classrooms of Tomorrow (ACOT) stages where this is a period of familiarization (Entry) representing baseline exposure to technology; utilization (Adoption) occurring when teachers try the technology, integration (Adaptation) beginning the appropriate use of ICT, reorientation (Appropriation) where ICT becomes a part of the learning context and evolution or revolution (invention) where there is a change in methods and media to facilitate learning. These stages are confirmed in long-term projects like the Apple Classrooms of Tomorrow (ACOT, 1995) studies which show that teachers must travel through a number of stages to integrate ICT fully into their classrooms and their teaching programmes and teachers must progress through all five phases, otherwise, the technology will likely be misused or discarded (Rieber and Welliver, 1989;Marcinkiewicz, 1994).

Moersch (1997) has reported his development of Levels of Technology Implementation (LOTI) framework which defines seven levels of the implementation of computers in a school. The levels are based on the original CBAM levels and are called: non-use awareness, exploration, infusion, integration (mechanical), interaction routine, expansion and refinement. From this framework, Moersch (1997) developed an instrument to calculate what he refers to as the computer efficiency at a school site. Computer efficiency is the degree to which computers are being used to support conceptbased or process-based instruction, consequential learning, and higher order thinking skills. The instrument accumulates the products of the LOTI level, proportion of computer use, proportion of student use and number of computers to produce an index for comparison between schools. However, the originators of concern-based models would not approve of such an instrument since it uses a questionnaire rather than observation and interview and uses numerical calculations to arrive at levels (Hall and Hord, 1987).

\section{Research question}

To what extent does the use of ICT improve the quality of teaching/learning related activities in Ogoja Education Zone.

\section{Design methodology}

The research design adopted for this study is the ex-post facto design because the 
researcher has no direct control of the independent variable as their manifestation had already occurred. The study was carried out in Cross River State, Nigeria. The population was made up of primary school teachers in Ogoja education Zone totaling 4,473 in 415 schools.

The sample for this study consisted of six hundred and twenty (620) teachers randomly selected from 62 primary schools in Ogoja Education Zone of Cross River State. A breakdown of the figure shows that teachers were selected from each of the sixty-two (62) primary schools sampled for the study.

A further breakdown of the figure as shown in Table 1 reveals that 100 teachers were selected from Bekwarra Local Government Area, 120 teachers from Obanliku Local Government Area, 120 from Obudu Local Government Area, 130 teachers from Ogoja Local Government Area and 150 teachers from Yala Local Government Area respectively.

TABLE 1: Distribution of sample by Local Government

\begin{tabular}{lll}
\hline LGA & NO. OF RESPONDANTS & PERCENTAGE \\
\hline Bekwarra & 100 & 16.13 \\
Obanliku & 120 & 19.35 \\
Obudu & 110 & 17.74 \\
Ogoja & 130 & 20.97 \\
Yala & 150 & 24.19 \\
Total & $\mathbf{6 2 0}$ & $\mathbf{1 0 0}$ \\
\hline
\end{tabular}

Data analysis/discussion: To what extent does the use of ICT improve the quality of teaching/learning related activities in Ogoja Education Zone.

TABLE 2: Response of the respondents on ICT improved the quality of teaching/learning related activities in Ogoja Education Zone ( $\mathrm{N}=620)$

S/N ITEMS

\begin{tabular}{|c|c|c|c|c|c|c|}
\hline & & \multicolumn{2}{|l|}{ A } & \multicolumn{2}{|l|}{ D } & \multirow[b]{2}{*}{ Total \% } \\
\hline & & $F$ & $\%$ & $F$ & $\%$ & \\
\hline 1 & $\begin{array}{l}\text { My lesson note preparation is } \\
\text { enhanced through skills acquired from } \\
\text { the internet. }\end{array}$ & 245 & 39.52 & 375 & 60.48 & 620100 \\
\hline 2 & $\begin{array}{l}\text { The new skills acquired from the } \\
\text { internet has helped me greatly in } \\
\text { sequencing learning activities for my } \\
\text { pupils. }\end{array}$ & 230 & 37.10 & 390 & 62.90 & 620100 \\
\hline 3 & $\begin{array}{l}\text { I can now use formulate meaningful } \\
\text { and reliable learning objectives for my } \\
\text { lessons }\end{array}$ & 253 & 40.81 & 367 & 59.19 & 620100 \\
\hline 4 & $\begin{array}{l}\text { I now have a better way of managing } \\
\text { and controlling my pupils during } \\
\text { lessons. }\end{array}$ & 206 & 33.23 & 414 & 67.77 & 620100 \\
\hline 5 & $\begin{array}{l}\text { I can use my computer to type my } \\
\text { lesson note, and effect necessary } \\
\text { correction. }\end{array}$ & 372 & 60 & 248 & 40 & 620100 \\
\hline
\end{tabular}


From Table 2, it can be observed that for Item 1, 245 (39.52\%) agreed that their lesson note preparation is enhanced through skills acquired from the internet, while $375(60.48 \%)$ did not. 230 teachers $(37.10 \%)$ agreed that the new skills acquired from the internet has helped me greatly in sequencing learning activities for my pupils, while 390 (62.90\%) did not. 253 teachers $(40.81 \%)$ agreed that they can now use formulate meaningful and reliable learning objectives for my lessons, while 367 (59.19\%) did not. 206 teachers (33.23) agreed that they now have a better way of managing and controlling my pupils during lessons, while 414 teachers $(67.77 \%)$ did not. The result also shows that 372 teachers $(60 \%)$ of the total respondents agreed that they can use their computer to type their lesson note, and effect necessary correction; while 248 teachers (40\%) did not.

The results of the analysis indicate that the percentage of disagreement for all the five Items is higher than 50. This implies that ICT improved the quality of teaching/learning related activities in Ogoja Education Zone.

\section{DISCUSSION OF FINDINGS}

Sutton (2006) who observed that ICT in education have been found to promote students' intellectual qualities through higher order thinking, problem solving improved communication skills, and deep understanding of the learning tool and the concepts to be taught. ICT can promote a supportive, interactive teaching and learning environment, create learning communities, and provide learning tools for students, including those with special needs. Kosoko-oyedeko and Tella (2010) also noted that ICT is observed to help pupils to learn and enabling them to consolidate and deepen their knowledge, understanding and skills. They also noted that lct is a powerful tool that can improve teaching and learning and can help to raise standards by encouraging pupils to ask questions to promote knowledge and understanding and shared human experience.

Becker (1993) in considering the role of teachers articulated the characteristics of exemplary computer-using teachers. He found that they integrated computers into their program and created an environment for learning in which the computer use was not only directly related to their curriculum goals, but also incorporated a wide variety of uses for the machine across the curriculum. Becker(1993) also noted that exemplary computer using teachers had greater access to formal professional development activities than other computer users he noted specifically that when directly related to specific subject areas, staff development in the use of generic software programs (eg. word processors) was beneficial.

\section{CONCLUSION/RECOMMENDATION}

Based on the findings of the study, the following recommendations are made:

1. Government should provide computers at affordable prices to all the teachers in the educational zone.

2. Teachers should organize or create awareness on Information and Communication Technology (ICT) to enhanced the student.

3. Government should provide necessary facilities that would guide against the constraints facing the use of ICT.

\section{REFERENCES}

ACOT., 1995. Changing the conversations about teaching, learning and technology: A report on 10 years of ACOT research. Frenchs Forest, NSW: Apple Computer Australia.

Becker, $\mathrm{H}$ and Chin, K., 1984. Computers in the schools: a recent update. Classroom Computer Learning, January: 96-102.

Becker, H. J., Raritz, J. L and Wong, Y. T., 1999. Teacher and teacher-directed students use of computers and software. (Teaching, Learning, and computing: 1998 National Survey,3). Irvine, CA: Center for Research in information Technology and Organizations, University of Califonia, Irvine.

Hall, G. E and Hord, S. M., 1987. Change in schools facilitating the process. Albany: State University of New York Press.

Hawkins, J. P., 2002. Locus of control and student teacher computer attitudes. Computers and Education, 14, (5): 421432.

Hawkins, R. J., 2002. Ten Lessons for ICT and education in the developing into the 
learning environment at Sevenoaks Senior College. Paper AID01027. Retrieved $10^{\text {th }}$ July, 2007 from http://www.nare.edu.au/01par/ ald012027.html.

Knee, R. H., 1996. The relationship of selected principal Characteristics to the integration of technology in schools. Unpublished doctoral thesis, Department of Information Technology, Florida Atlantic University.

Kosoko-Oyedeko, G. A and Tella, A., 2010. Teacher's perception of the contribution of ICT to pupils performance in Christian Religious Education. Journal of Social Science, 22, (1): 7-14.

Mann, D., 1999. West Virginia story: achievement gains from a state-wide comprehensive instructional technology program. Milken Exchange. Retrieved October $20^{\text {th }}, 2009$ from www.milkenexchange.org.

Marcinkiewicz, H. R., 1993. Computer and teachers: factors influencing computer use in the classroom. Journal of Research in Computing Education, 26, (2): 220-237.

Moersch, C., 1997. Computer efficiency: Measuring the Instructional use of technology, Learning and Leading With Technology, (December), 11-16.
National Curriculum in Action., 2007. Religious

Education: ICT. Learning. Retrieved July 10, 2007 from http://www.ncaction.org.uk/index.html

Poole, G. A., 1996. A new gulf in American education: the digital divide. New York Times, January 29.

Richer, L. P and Welliver, P. W., 1989. Infusing educational technology into mainstream educational computing. International journal of Instructional Media, 16(i), 2132.

Rieber, L. P and Welliver, P. W., 1989. Infusing Educational technology into mainstream educational computing. International Journal of Instructional Media, 16, (1): 21-32.

Rogers, E. M., 1983. Diffusion of innovations $\left(2^{\text {nd }}\right.$ ed.). New York: The Free Press.

Sulton, B. B., 2006. Pedagogy and curriculum. Centre for Media in Community, EDC. Retrieved July 10, 2007 from: http://www.digitaldivide.net/news/view.ph $\mathrm{p}$ ?headlinelD=701. 